\title{
Globalisation: The Political Dynamics
}

\author{
Robert A Schrire
}

Department of Political Studies, University of Cape Town

\begin{abstract}
Globalisation is a multidimensional phenomenon and should be conceptualised as a process rather than an outcome. Economic, political, cultural and societal elements are involved in the complex set of interactions we can define as globalisation. However, a key factor, which is frequently ignored is the importance of politics in shaping and guiding this process. For example economic liberalisation and deregulation, the form which economic globalisation has thus far taken, did not emerge from impersonal market and technological forces. Governments, especially those of the United States and Great Britain, followed explicit policies of currency controls relaxation, the reduction in trade barriers, and the retreat in the role of the state in the economy generally. Despite the power of the economic forces thus released, politics remains a key potential player and globalisation is not necessarily irreversible. Given the indeterminacy of the outcomes of globalisation, four alternative theories of the future are presented and analysed.

JEL F 02
\end{abstract}

\section{INTRODUCTION}

Globalisation has since the early 1990 s become one of the most frequently used concepts in the social sciences ${ }^{l}$ and is a strong contender for the most commonly used term in the public debates. It is often used indiscriminately to describe almost all modern developments - good and bad - and thus usually generates more heat than light. Indeed social science methodology confirms that a concept that purports to explain everything in fact explains nothing.

This threatens to be the fate of the concept of globalisation. Protestors representing a wide range of diverse views and operating from such geographically distant cities as Seattle and Genoa, mobilise against its alleged evils while bureaucrats from the International Monetary Fund, World Trade Organisation, and World Bank are staunch in its defence. Because the concept is so rarely defined with care and rigour, it has tended to become a catch-all concept which is often used to express widespread discontent with modernity and its disruptions. Yet even before we begin the task of defining and analysing a complex and dynamic 
concept, a moment's reflection should convince the rational observer that globalisation, however defined, cannot be held responsible for the wide array of popular grievances attributed to it. For example, many environmentalists blame globalisation for the decay of the environment. However, given that systems of production are located in geographically defined states, it is the actions and inactions of governments in states such as China, India and the United States that must shoulder the responsibilities for pollution. Globalisation has little if anything to do with these realities. Similarly, the decline in the viability of small farms and village business centres is not a consequence of the forces of globalisation, but reflects the economies of scale which favour large agribusiness and hypermarkets.

What is globalisation? Or phrased differently, if concepts are neither true nor false in and of themselves, how best can we think about the complex range of changes which are subsumed by the ideas of the critics and supporters of "globalisation?" Globalisation is clearly a multi-dimensional phenomenon. Economists tend to equate globalisation with the process of economic liberalisation and deregulation. The contemporary global market is in the process of transcending the boundaries of the state system. If this process reaches its logical conclusion without major political interference, an economic system liberated from the restraints of political sovereignty will have been created. Empirically this would be measured by the growth in transnational capital flows, the liberalisation of trade and, arguably, by the emergence of large corporations controlled and managed free from the restraints of a particular nation. Transnational corporations would be owned and managed by a global constituency of shareholders and managers.

For many sociologists, globalisation is viewed as the process, which is creating a global culture characterised by the dominance of the English language rationalism, materialism and individualism. Many political scientists tend to see globalisation as the process that is carrying liberalism and democracy to universal victory. Some analysts maintain that this process is threatening the state system itself because its defining characteristic - sovereignty - is being undermined ${ }^{2}$.

Two problems emerge from this brief discussion. First, it is clearly dangerous to divide a complex phenomenon into discrete disciplinary specialties. It has long been recognised, and bemoaned, that economists and political scientists have generally ignored each other's work even in areas where there are considerable overlaps. Secondly, globalisation must be conceptualised as a process and not as an outcome. While it should be possible to analyse empirically the determinants of globalisation, the outcomes are not path dependent and must thus be considered indeterminate. 
What are the processes driving globalisation? Almost all scholars agree that technology, especially in the field of communications, is perhaps the most important influence on contemporary economic and political life. The world today is profoundly different from the past. Technology for example, has made possible actions, which enable vast magnitudes of funds to be transferred almost instantaneously to any part of the world. Similarly, the ability of a global audience to have instantaneous access to information about political riots in the Middle East, the forcible confiscation of land in Zimbabwe, or the confusions around Americas recent presidential election, all have profound implications.

How should we define globalisation? It follows logically from the discussion above that globalisation, however defined, must be conceptualised as both a process and as a multidimensional phenomenon. Incorporating elements of Anthony McGrew's definition ${ }^{3}$, I would define globalisation as the processes, based upon technology, which increase both the speed and scope of linkages across state boundaries in areas including the economy, polity and culture.

The implications of this definition are profound and cannot be explored in detail here. But the following should be noted: 1) the process of globalisation need not be irreversible, 2) globalisation in one sphere may not be matched by similar dynamics in another, and 3) the processes of globalisation in the various spheres may, in fact, be in conflict with each other. In the remainder of this article, I will briefly examine some of the implications of these factors for the politics of globalisation in the context of the larger processes of change.

\section{POLITICAL DYNAMICS}

From a legal perspective, international politics is still based upon the Westphalian legacy of independent and sovereign political states. Indeed, the most universalistic global institution, the United Nations, was established by sovereign states and its founding charter pays explicit tribute to sovereignty and noninterference in the domestic affairs of its members.

During the Cold War, this state oriented paradigm retained considerable relevance. The world was locked in a titanic struggle between two superpowers, each with its associated vassals and allies. Despite the ideological pretensions of this struggle, there were also important geo-political and nationalistic elements. Indeed, many theorists argue that the distribution of power in an international system dictates the kind of configurations of conflict in that system ${ }^{4}$. The bipolar contest between 1945 and 1990 had several important characteristics. Firstly, economics was frequently subordinated to the political requirements of the contest. National interests, defined largely in terms of power, were paramount. 
From a policy perspective, the distribution of gains (and losses) was more important than the absolute gains. The market was to a large extent subordinate to the polity. For example capital, was not permitted to seek freely its highest return, trade was guided in political directions; many products were not allowed to be exported to potential rivals while allies frequently received special preferences. Thus, the then Soviet Union subsidised the economies of allies such as Cuba and the German Democratic Republic both to bind them closely to the superpower and to prevent internal dissent in the periphery. Similarly, France tried to protect its political influence in Francophone Africa through policies such as currency arrangements and preferential trading agreements. These political imperatives did not totally override the market except in the Soviet bloc. But even the western capitalist states limited the autonomy of the market to create and distribute economic values.

A second important consequence of the Cold War was the downplaying of the importance of domestic factors in the choice of both allies and foes. Although the superpower conflict was ostensibly solely over ideological concerns, the reality is that Realpolitik overrode ideology. For example, the United States, despite its liberal and capitalist orientation, supported overtly and consistently a wide range of authoritarian regimes such as Chile and, in the 1960s and 1970s, South Africa, as well as several market unfriendly regimes in Africa and Latin America. The key to American support was not primarily the nature of a state's political economy but its foreign policy orientations. States that were avowedly anti-communistic were almost automatically assured of US support. Similarly the Soviet Union, despite its more explicit ideological self-image, supported a wide range of African and Asian states such as Ghana, Angola and Cambodia whose actual economic policies bore little resemblance to genuine socialism.

A third implication of the end of superpower bipolarity has been the decline in the autonomy of many small states. During the Cold War, states such as Zambia had some scope for maneuver because they could play off one superpower against the other. Given the importance then of bilateral aid, this could be a rewarding strategy. The end of superpower competition has made such a strategy unviable with significant implications. For example, contemporary Zambia has international debts of about six billion dollars - about twice the size of its national income. It only survives on global handouts which constitute half the governments budget. The world can now dictate the terms of its engagement with Zambia. In the past, Zambia would have retained some autonomy - under cold war conditions, President Chiluba would not have been forced to abide by the constitutional prohibition on seeking a third term.

During the cold war the international system was structured around the principle of a balance of power which also largely served to ensure order. The so-called 
universalistic organisations such as the United Nations had no independent capabilities and were essentially paralysed by the mutual veto enjoyed by its permanent members. Economic organisations such as the IMF and World Bank were for western states only while the Soviet Union created its own exclusive organisations such as COMECON.

\section{THE FALL OF COMMUNISM}

When the Cold War ended in the early 1990s, bipolarity ended with it. The world became characterised by the effective hegemony of the United States as the world's only superpower. However, in a world where many different types of power exist, the United States alone was not able to dominate all aspects of the global political agenda. But if the US could not dominate, it exercised veto power in most areas of public international policy.

The attention of intellectuals turned to the new paradigm of "globalisation". Most observers, aware of both the growing complexity of the modem world and the inability of the remaining superpower to dominate the system in its entirety, sought a systemic explanation for this seeming paradox. The thesis that new forces led by the markets had emerged outside of political control seemed to provide a useful explanation. This is, however, a profoundly ahistorical perspective. Globalisation did not emerge $a b$ initio from uncontrollable systemic forces. Political decisions with intended and unintended consequences made possible the spread of technology. Major powers, following their own perceived interests, set in motion policies of economic liberalisation. When the perceived political imperatives of a Marxist challenge began to decline, the major powers, especially the United States and Great Britain, liberated the market on a global scale. The process of trade liberalisation, which began with the formation of GATT, continued with the inclusion of the former Soviet Union and most of its allies. Capital was largely liberated from regulations and controls - the result of deliberate government decisions, first in the United States and Great Britain and then spreading throughout the industrialised world. With the unimportant exceptions of a handful of states such as Cuba and Iraq, trade was largely liberated from political controls.

\section{IMPLICATIONS AND TRENDS}

In economic theory the consequences of economic liberalisation are unambiguous and generally positive. A large literature, both theoretical and empirical exists describing the outcomes of economic integration, trade liberalisation and capital mobility ${ }^{5}$. We have case-studies of the empirical outcomes in the United 
States and increasingly the European Union. Unimpeded by political factors, economic globalisation will lead to the emergence of a global economy in which resources are allocated on the basis of efficiency rather than geography or politics.

However, in the political sphere the implications of globalisation for both domestic and global politics are problematic and probably indeterminate at this stage of History. Economic liberalisation has advanced far more rapidly than political integration. Although the scope of economic globalisation has been exaggerated $^{6}$, we can nonetheless trace empirically an emerging global economy. However as noted earlier, the political system remains based, frequently fictitiously, on the notion of sovereignty.

Generally, the most important of the existing trends can be said to be: the discontinuities between economic globalisation and the state system; the rapid pace of technological change; the power and spread of Western ideas; and the tentative emergence of a nascent global civil society. While all of these would require a rigorous analysis, this is not possible for the scope of this article. However, it may be useful to explore some of the possible outcomes of these forces. Given our conceptualisation of globalisation as a process, what are the possible political outcomes? Broadly, we can distinguish between the following possibilities: the re-emergence of Realpolitik; the end of sovereignty; the return of the state, and/or global governance.

\section{THE RE-EMERGENCE OF REALPOLITIK}

The end of the Cold War largely liberated the market from political controls. Although many market optimists believe that this victory is irreversible (see below), others argue that this victory is a delusion. The political kingdom is far too well entrenched in human society to be so easily vanquished. Conflict is endemic and will re-emerge sooner or later in one form or another.

One of the most prominent advocates of this position is Samuel Huntington? ${ }^{\text {. He }}$ argues that globalisation is bringing Western ideas to all parts of the globe while economic integration is penetrating many non-Western societies. Contrary to the view of the optimists, growing contacts will lead not to harmony and a shared materialism but to increased conflict and turbulence. The conflicts will not be based upon traditional state conflicts or ideologies but upon a clash of civilisations. In Huntington's view, "the most important conflicts of the future will occur along the fault lines separating these civilisations from another" 
Other pessimists reject the Huntington analysis but agree that conflict cannot be eliminated from global affairs. They maintain that states will remain the key players in the future and that the present harmony which characterises relations between the major powers will be temporary. In the view of neo-realists it will be systemic forces, which lead "states [to] balance against hegemons". The present dominance of the United States will in time produce an inevitable countervailing force. One possibility would be for a politically united Europe to challenge US hegemony. More destabilising for political stability would be the emergence of new and revisionist superpowers like China and India which would be unlikely to accept a world created in Westem, and especially, American images. And the former superpower represented by contemporary Russia could, in time, become an important revisionist power. Recent negotiations between China and Russia to establish the Shanghai Five might be seen as the beginning of such a process.

\section{THE END OF SOVEREIGNTY}

The high priests of economic globalisation like Ohmae ${ }^{10}$ and Friedman believe that the conflict between the state and the market is already largely over and the market has emerged victorious! The imperatives of economic liberalisation have overcome the reactionary forces represented by the state. Grand ideologies and petty but destructive nationalisms are largely dead. Where they do still exist - in Bosnia, China and Nigeria - they are restricted to backward societies, which represent the past rather than the future.

In all of today's advanced and dynamic societies - in North America, Western Europe, Australia and Japan - governments have rejected the destructive nationalisms of the past while the populace has rejected the grand designs of the state. People there seek personal fulfillment and improved material welfare. And they will use their vote to punish any political movement, which seeks to return to the past. In the words of then American presidential candidate Bill Clinton, "its the economy stupid!"

In addition, the costs of attempting to unravel the threads of today's economic liberalisation would be too high for any rational government to even consider. Power now lies squarely with the giant corporations, which control the world's major accumulations of capital and dominate the creation and dissemination of technology and intellectual capital. Even formerly radical states in Africa, Asia and Latin America are competing fiercely with each other to become integrated into the global economy. 


\section{THE RETURN OF THE STATE}

Neo-realists reject both the return to conflict paradigms and these economically deterministic conclusions. They believe that the extent of globalisation has been grossly exaggerated. The state remains a key player - especially the United States. The state economy remains far more important than the global economy. Thus, they reject the claim that transnational corporations are becoming dominant players. Indeed they reject the basic concept of a transnational company. Corporations may have global operations but they remain state based: they operate from geographically defined headquarters, they are legal creations of particular jurisdictions, and states remain the dominant authority in regulatory and tax policies $^{11}$. Indeed the policies of states towards private enterprise, property rights and education remain a vital element in the prospects for success or failure of the corporate sector ${ }^{12}$. Politics thus remains in control - at least in the major states. If countries like Peru, Thailand, Ghana and Namibia lack genuine autonomy, this is not the consequence of globalisation. Historically, minor powers have never had real power in a world dominated by the consequences of the inequalities in the distribution of power. Globalisation is not an explanation for powerlessness but a conceptual confusion resulting from an ahistorical mode of analysis.

Above all, neo-realists see the contemporary world as in large part the creation of the major players, especially the United States and Great Britain. To put it in the words of Susan Strange, these major powers had "structural power", i.e., "the power to decide how things shall be done, the power to shape frameworks within which states relate to each other, relate to people, or relate to corporate enterprises" 13 . With the end of the cold war they perceived that their interests, and those of their citizens, would be served by a liberal economic order. If economic liberalisation is the result of political decisions, then it can in principle be controlled. No mainstream scholar has advocated a return to autarchy. However they reject the argument that globalisation is the outcome of systemic forces which can be neither controlled nor reversed. Globalisation remains in the interests of the superpowers and their domestic elite. And should these interests change, states acting singly and collectively would have both the power and the will to reassert political control over the market.

\section{GOVERNANCE}

The final perspective is more complex and nuanced than any of the preceding approaches. The governance perspective accepts the important role that the state has to play in resolving conflicts, providing public goods including security, and regulating an increasingly complex society and environment. Proponents of the 
governance perspective argue that although the state is not obsolete, it cannot continue with business as usual in a complex and interdependent context. The key global players have transcended conflicts of the past - be they based upon state, culture or ideology. However it is utopian to expect a global system of govemment to emerge under present circumstances. They also reject the hyperglobalist argument of the victory of the market, which implies that politics is of very limited importance. However, despite the absence of a global government or system of authority, the global community is not in chaos. The functions of govermment can be performed even in the absence of govermment. A system is emerging in which a complex web of institutions and groups is performing some of the functions of government. Contemporary global organisations like the WTO have far more actual authority than an earlier generation of institutions like the UN system and the World Bank because it is not legally dominated by any power. And unlike the UN and, de facto, the IMF and World Bank, the WTO does not have a veto mechanism.

New global institutions, despite their fragility, are increasing and are being complemented by regimes - systems of rules and norms, which sovereign states are increasingly accepting voluntarily ${ }^{14}$. Self-interest does not have to produce a Hobbesian world of conflict and anarchy. Rational actors can learn from experience how to cooperate with other independent players. Although this emerging system is not directly democratic, it is being supported by a range of NGOs, which now constitute the beginnings of a global civil society. Ecologists, human rights activists and others concerned with global issues are using modern technology to cooperate across state boundaries. A new political dynamic is developing - not as a replacement for states and governments but as democratising and supplementing forces.

Governance without government is epitomised by the emergence of tribunals for justice. Despite the admonition against interference in the domestic affairs of sovereign states, a global sense of community is slowly emerging. The arrest of former Chilean dictator Augusto Pinochet in Britain at the request of a Spanish prosecutor was a harbinger of this development. This trend has accelerated with the arrest and prosecution of former Yugoslav leaders including Milosevic. This new direction in global affairs is now becoming formally instutionalised. In 1993, the Intemational Criminal Tribunal for the Prosecutions of Persons Responsible for Serious Violations of International Humanitarian Law Committed in the Territory of the former Yugoslavia was established and in the following year a similar body was established for Rwanda. Both bodies were created under the auspices of the Security Council. A more ambitious development is the proposed International Criminal Court also under the auspices of the United Nations. Thus far, thirty six of the sixty states required for its establishment have ratified the proposal. If it is established it will represent a major advance in giv- 
ing meaning, through possible retribution, to the commitment to the protection of global human rights.

\section{DISCUSSION}

It has been a central contention of this article that the future has not yet been irrevocably written. Unlike advocates of a "return to history" or "Sovereignty-atbay", I believe that various outcomes remain possible.

The key weakness of theories, which predict the re-emergence of Realpolitik, is that they are trapped in a view of history where peoples and states are caught in a world of conflict. Despite the publicity accorded to Huntington's "clash of civilizations", few conflicts today are exclusively or even primarily about culture, however defined. Similarly, although it is possible that revisionist states like China may emerge to challenge the status quo, it is not inevitable that this will happen. And thus far no state has advocated a global system fundamentally different from the contemporary world. Rather than transformation, critics are demanding faimess - in the composition of the Security Council, in voting weights in the IMF, and in general for greater democracy and transparency.

Similarly, proponents of the view that markets have or will override the polity have a simplistic and deterministic view of causation in human societies. A central theme of this article has been the political dynamic behind economic liberalisation. And what the polity has created, it can also destroy.

Many useful insights are contained in the works of the advocates of a "return of the state" and "global governance". Politics, domestically and globally, remains dominant. Power politics has not been eliminated. However, the world has changed dramatically and it is not business as usual in global politics. New issues have arisen - ecology for example - while sovereignty takes a different form in a world of interdependencies and hyper-complexity. Technology makes cooperation between individuals and groups and organisations possible in a way that was unthinkable in the past.

The future will look both similar to and different from our recent past. There will be continuities and discontinuities. States will continue to be the principal actors but they will share the stage with NGOs, regional bodies and global organisations. Power and security will continue to be central issues but they will be joined by issues of human rights, the protection of the environment, and the pursuit of justice. The past, present and future will be joined simultaneously! 


\section{CONCLUSIONS}

The end of the Cold War then, has witnessed the general decline in the importance of explicitly political factors in the formulation and implementation of economic policy, the rise in the importance of economic values and thus the increased importance in the role of the market in shaping resource allocation and distribution decisions. One major, consequent problem has been the growing imbalance between the market and the polity. While economic forces have been largely liberated from state regulation, no global mechanism has been created to perform the traditional functions of governance. This problem is most urgent in the area of capital flows. In a single polity with a common currency, the movement of capital has limited political relevance. However, in a world in which states remain the organisational framework, the free movement of capital can have profoundly destabilising consequences. This is compounded by the relative immobility of labour. Historically, mass migrations have been a powerful redistributive force which have dramatically contributed to the reduction in inequalities between states.

The implications for economic stability and macroeconomic policy of the imbalance between political and economic globalisation fall outside the scope of this article. But in the sphere of hot money, i.e., the billions of dollars floating through the system derived from drugs and other criminal activities, the lack of a global authority or regulatory mechanism has important consequences for the conduct of political life. More generally, the problem lies in the failure of states to develop a mechanism for global political governance. The decline in economic autarchy has taken place in the context of sovereign states who are reluctant to cede any of their legal authority. None of the so-called international organisations are genuinely international. From the United Nations system to the International Monetary Fund and the World Trade Organisation they remain state-based. The world's only superpower dominates this system and few, if any, significant decisions can be made without US support. It should be stressed that this problem has not been created by globalisation. For most states, historically and up to the present, the idea of equality and autonomy has always been a myth. The major powers in all systems, from the seventeenth century to the present, have been dominant. If the superpowers have always made history, the minor powers have had to adjust to that reality. Globalisation has simply made this reality more stark. 


\section{ENDNOTES}

1 Busch, A. (2000) "Unpacking the Globalization Debate: Approaches, Evidence and Data", in Hay C. \& Marsh D., Demystifying Globalization, London: MacMillan Press.

2 See, for example, Susan Strange (1996) The Retreat of the State: Diffusion of Power in the World Economy, Cambridge: Cambridge University Press.

3 Anthony McGrew (1992) "A Global Society?", In Hall S., Held D. \& McGrew A. (eds.) Modernity and its Futures, Cambridge: Polity Press.

4 Kenneth Waltz (1979) Theory of International Politics, New York: Random House.

$5 \quad$ See, for example, World Bank (1996) "Liberalization, Stabilization and Growth" in World Development Report: From Plan to Market, Washington D.C.: World Bank.

6 Robert Schrire (2000) "The Duality of Globalization", Cambridge Review of International Affairs, 14(1): 52-58.

7 Samuel Huntington (1993), "The Clash of Civilizations?", Foreign Affairs, Summer.

$8 \quad$ Ibid, p.25.

9 Christopher Layne (1993), "The Unipolar Illusion: Why New Great Powers will rise", International Security, 17(4).

10 Kenichi Ohmae (1990) The Borderless World, London: Collins; and (1995), The End of the Nation State, New York: Free Press.

11 P. Doremus, W. Keller, L. Pauley \& S. Reich (1998), The Myth of the Global Corporation, Princeton: Princeton University Press.

12 Michael Porter (1990) The Competitive Advantage of Nations, New York: Free Press.

13 Susan Strange (1988) States and Markets: An Introduction to International Political Economy, London: Pinter: 24-25.

14 See, for example, Robert O. Keohane (1984) After Hegemony: Cooperation and Discord in the World Economy, Princeton: Princeton University Press.

\section{REFERENCES}

1 BUSCH, A. (2000) "Unpacking the Globalization Debate: Approaches, Evidence and Data", in Hay C. \& Marsh D. (eds.) Demystifying Globalization, London: MacMillan Press.

2 DOREMUS, P., KELLER, W., PAULEY, L. \& REICH, S. (1998) The Myth of the Global Corporation, Princeton: Princeton University Press.

3 MCGREW, A. (1992) "A Global Society?", In Hall S., Held D. \& McGrew A. (eds.) Modernity and Its Futures, Cambridge: Polity Press. 
4 HUNTINGTON, S. (1993) "The Clash of Civilizations?", Foreign Affairs, Summer.

5 KEOHANE, R.O. (1984) After Hegemony: Cooperation and Discord in the World Economy, Princeton: Princeton University Press.

6 LAYNE, C. (1993) "The Unipolar Illusion: Why New Great Powers will rise", International Security, 17(4).

7 OHMAE, K. (1990) The Borderless World, London: Collins.

8 OHMAE, K. (1995) The End of the Nation State, New York :Free Press.

9 PORTER, M. (1990) The Competitive Advantage of Nations, New York: Free Press.

10 SCHRIRE, R. (2000) "The Duality of Globalization", Cambridge Review of International Affairs, 14(1): 52-58.

11 STRANGE, S. (1988) States and Markets: An Introduction to International Political Economy, London: Pinter.

12 STRANGE, S. (1996) The Retreat of the State: Diffusion of Power in the World Economy, Cambridge: Cambridge University Press

13 WALTZ, K. (1979) Theory of International Politics, New York: Random House.

14 WORLD BANK (1996) "Liberalization, Stabilization and Growth" in World Development Report: From Plan to Market, Washington D.C.: World Bank. 